

Crome, Andrew (2018) Plugging Into the Papal Mainframe: The Political Role of the Church in Steven Moffat's Doctor Who. Journal of Popular Television, 6 (2). pp. 213-226. ISSN 2046-9861

Downloaded from: https://e-space.mmu.ac.uk/618460/

Version: Accepted Version

Publisher: Intellect Ltd.

DOI: https://doi.org/10.1386/jptv.6.2.213_1

Please cite the published version 


\section{Plugging Into the Papal Mainframe: The Political Role of the Church in Steven Moffat's Doctor Who}

The presence of the Church quite literally looms large over Matt Smith's tenure as the Doctor. Appearing at crucial junctures in each series in which he played the iconic Time Lord, his final episode featured the imposing presence of the Papal Mainframe - an enormous, peacekeeping spaceship which controlled the skies of the planet on which his character made his final stand against his ancient foes, the Daleks. The Church in the series was not lacking in either confidence or ability to control its (universal) congregations - it acted as a galaxy-wide 'security hub', protecting the innocent and playing a key role in the Doctor's ultimate vindication. The prominent role given to the Church is unusual in British television, and particularly so in science fiction. This article aims to examine what this placing of the Church might suggest about contemporary British understandings of Christianity, and what comment it offers on a variety of ecclesiastical perspectives on potential political roles for Christian organisations. The use of the Church in Doctor Who works on several levels, displaying nostalgia for a lost world, tying the show into ideas of British heritage and traditional television, and suggesting unease at the radicalising potential of religious belief. Doctor Who's use of the Church is therefore neither an unproblematic example of the secularisation of Britain, nor evidence for a newly emerging religiosity. Rather, it reflects the continuing confusion among the British public regarding the role and future of the Church.

Before examining these issues, it is important to introduce the position that the Church occupies in the Doctor Who universe. The organisation first appears in 2010 episodes 'The Time of Angels' and 'Flesh and Stone'. Set in the fifty-first century, the episodes find a militarised Church in which surplices and dog collars have been replaced with army fatigues and explosives. As the Doctor tells his companion Amy Pond, the 'Church has moved on.' Soldiers are divided into ecclesiological ranks (from Cleric to Bishop) and given 'sacred names' (ranging from 'Angelo' and 'Christian' to the more prosaic 'Bob'). The Doctor appears willing to work with the Church, professing his admiration for the soldiers' 'Bishop' Father Octavian, while also offering a critique of the organisation's theological opposition to two-headed beings 'self-marrying'. The Doctor's next encounter with the Church, in 'A Good Man Goes to War' (2011), is less positive. The Church now appears to be complicit in Amy's 
kidnapping, working with 'The Order of Headless Monks' to develop a strategy to destroy him. The somewhat ambiguous nature of the Church's relationship to the Doctor was finally explained in Matt Smith's final episode in the role, 'The Time of the Doctor' (2013). Those dedicated to the Doctor's destruction are revealed to be a breakaway sect, with the Church itself shown to have a key role in enforcing security and maintaining peace throughout the galaxy. The Church of Steven Moffat's Doctor Who is therefore not a powerless, irrelevant organisation, but one that is intimately concerned with the public good, acting as a check on the imperial ambitions of the Doctor's enemies.

The image of the Church is therefore unclear, and at times counterintuitive. The Church boasts a hierarchy, prayer, and solid moral positions, making it analogous to contemporary ecclesiastical organisations. The Church's ships are marked by architectural elements such as transepts, and the symbol worn by soldiers represents the Greek letters alpha and omega; that is, God's claim that he is both the first and the last (see Revelation 1:8, 21:6, 22:13). Yet at the same time it appears to be an institution in which theology plays little or no role - an Ecclesia with the trappings of faith but bereft of its content. Similarly uncertain is the form in which the Church is portrayed. At times, its military identify as Church of England (e.g. 'the thin fat gay married Anglican marines' in 'A Good Man Goes to War'), while at others explicitly Catholic terminology is used - the Church is run by the 'Papal Mainframe', 'Father' is an accepted designation, and it boasts a 'Mother Superious'. It is a potentially confusing picture, but one which reflects the contemporary British ambivalence towards the Church of England, and growing confusion about theological differences between denominations.

As Marcus Harmes (2013b) has pointed out, the role that Moffat envisions for the Church is markedly different from the usual portrayal of the future of Christianity in science fiction. This has tended to focus on a dystopic fundamentalism as part of post-apocalyptic society: the state-controlled Church in Alan Moore's V for Vendetta (1988) or the crippling fundamentalism of Margaret Atwood's The Handmaid's Tale (1985), for example. While several sci-fi novels, such as James Blish's A Case of Conscience (1958) and Mary Doria Russell's The Sparrow (1996) have dealt with Catholic missions to new civilizations (Hrotic 2014), the future church has rarely played a major role in science fiction television, particularly in Britain. Indeed, Harmes suggests that the Church of England is usually 
portrayed as succumbing to the challenges of a changing world in series such as Quartermass and the Pit (1958) and Day of the Triffids (1981) (Harmes 2013a). This is also true for both the revived Doctor Who and the classic series of the show. While the Doctor's nemesis, the Master, may have concealed himself as the Reverend Magister in 'The Daemons' (1971), and Nicholas Parsons's Reverend Wainwright lost his faith due to the Church's wartime complicity in the bombing of civilians in 'The Curse of Fenric' (1989), there was no sense in which the Church was examined as an institution, or seen to have any political impact. Instead, depictions of the Church on the show further supported a thesis of institutional decline and decay (Harmes 2013a). When Doctor Who returned to the air in 2005 under showrunner Russell T Davies, there was little suggestion that institutional religion would thrive in the future. Although a professed Atheist, Davies's view of religion was often ambiguous. While religion was at times classed as a social evil banned from civilised gatherings ('The End of the World' [2005]), a form of belief does appear to survive (as seen in 'The Impossible Planet/The Satan Pit' [2006]), and an episode set in the year five billion and fifty-three finds a society stabilised by corporate hymn singing ('Gridlock' [2007]). Yet although Davies's presentation of religion in the series was often conflicted (Balstrup 2014; Crome 2013, 2015), his episodes focused on personal religiosity rather than organised religion. In 'Gridlock', for example, hymns function as a form of social cohesive in lieu of the authorities who had been wiped out twenty years earlier.

On some levels, it is unsurprising that the Church has not had a significant role in Doctor Who. Religious historians have long argued that secularisation has had a major impact on the role of religion in British public life, and the reduction of interest in the Church might therefore appear to be logical. The institutional decline of religion has often been seen as part of the process of modernisation, linked to increasing individualism and privatisation of faith with roots in the early modern period (Bruce 2011, Gregory 2012). Others have suggested that the decline in faith can be linked to a religious crisis in the 1960s (Brown 2009, McLeod 2007). General church attendance has continued to decline, and the numbers identifying as Christian also decreased significantly from the 2001 to 2011 census (Office for National Statistics 2012). This decline is perhaps reflected in popular portrayals of the Church in other television shows. British television has a long tradition of ecclesiastical sitcoms, stretching back to All Gas and Gaiters (1966-1971), taking in recent popular shows such as The Vicar of Dibley (1994-2007), Father Ted (1995-1998) and Rev. (2010-2014). Each of these shows 
engaged with religious decline in slightly different ways, with the urban realism of Rev. displaying the challenges of dealing with shrinking attendances and morale in the most explicit terms. This approach is in marked contrast to Father Ted's surreal satire on Irish Catholicism (Hill 2016), and The Vicar of Dibley's avoidance of humour specifically at the Church's expense (Krämer 2016). Whereas the Church of Rev. was portrayed as incapable of genuine political influence as it struggled with urban decline, in The Vicar of Dibley the Church was instead chiefly a communal organisation which, like the rest of the idyllic (and all white) village of Dibley, appeared to hark back to a nostalgic concept of rural English life. It is noteworthy that this approach garnered large ratings, and that the show's major detour into politics (in promoting the 'Make Poverty History' campaign in 2005) drew criticism from both viewers and the BBC Trust (Holmhead 2007).

The portrayal of the Church on British television might, therefore, be read as being just one symptom of its declining influence in society as a whole. An important element of Stig Hjarvard's theory of the mediatisation of religion (in which media takes over many of the social functions previously undertaken by organised religion and religious organisations become reliant on media logic) is the concept of 'banal religion'. Religious images become dislodged from their institutional and theological contexts, and become raw material that producers use as shorthand for concepts of the sacred, or to impart a character's religiosity (Hjarvard 2011). The Vicar of Dibley's success could be read within this framework, as the Church setting provides 'an unthought about backdrop of cultural meanings' (Brown and Lynch 2012, 344) which evoked a sense of a nostalgia for a lost 'traditional' England (Krämer 2016). The Church in Doctor Who may be interpreted in much the same manner. The Church survives into the far future, offering a reassuring picture of the persistence of key British institutions in a time of political uncertainty. In one of Moffat's first episodes as showrunner, 2010's 'The Beast Below', the Doctor materialised on 'Starship UK', a giant spaceship housing the British nation. The presentation of the UK was marked by nostalgic and traditionalist imagery including a focus upon the monarchy, 1970s-style BBC broadcasts on board ship, and children in public school uniforms. Markers of British culture and identity survive long into the future, and the Church's longevity can be seen as one part of this. The use of the Church therefore invokes a kind of futurist nostalgia for a lost Britain through the projection of an imagined future. Yet the focus on the Church might also be interpreted in the context of production and marketing, and of Doctor Who's international appeal. As Simone 
Knox has noted, the show is often coded as both 'heritage' television (in the vein of 'quality' British period dramas) and as embodying a form of British eccentricity. This represents part of the show's appeal in the US market (Knox 2014). The use of the image of an detheologised Church as a galactic peace-keeping force recalls images of heritage television in terms of design (as seen in the sumptuous classical interiors of Mother Superious Tasha Lem's chapel) and through its invocation of the traditional role of the Church in British life. The Church's eccentricity, in it its use of sacred names such as 'Bob', (literally) Headless monks and the requirement that all visitors to the Papal Mainframe be naked, suggests ways in which Moffat's portrayal of the Church fits with Knox's analysis of the show's marketing.

Yet the story of Christianity in contemporary Britain is more complex than merely one of institutional decline (Guest et al 2012). Michael Hoelzl and Graham Ward have discussed the 'new visibility of religion' in the public sphere, as religion has become an increasingly important political issue - whether through the challenges of dealing with fundamentalism, the role of faith schools, or the engagement of church groups in the Big Society (Ward and Hoelzl 2008). In this context the Church of England has attempted to engage more assertively in political discourse. As a recent report from the think-tank Theos concluded, the Church has actively re-asserted its voice in public debates, often in ways which are critical of government (Glover 2011). This idea of a new visibility of religion does not argue for a religious revival, but for an increased awareness of the importance of religion and willingness to engage with it politically. In this context, the appearance of the Church as a political force in Doctor Who is understandable, despite declining attendance figures.

\section{The Church's Role}

The Church in Moffat's Doctor Who is an organisation which appears to have official duties and responsibilities while at the same time being disassociated from any particular polity. When we first encounter the body as an investigative unit in 'Time of Angels', they are working with the Doctor's imprisoned wife River Song in a capacity that seems to be something between law enforcement and a military mopping-up unit. While we do not learn of any supposed connection to human (or non-human) political structures, the Church clearly 
has a punitive and rehabilitative function, with the right both to utilise River Song's skills in custody and offer her a pardon should she succeed. In 'The Time of the Doctor' we discover that this role is far more extensive than suggested in the 2010 episodes. The centre of the Church, the 'Papal Mainframe' is described by the Doctor as 'the security hub of the known universe... keeping you safe in this world and the next.' The role of the Church here is active and superior to the political powers it polices. This episode provides context for the Doctor's other meeting with the Church - opposing him in 'A Good Man Goes to War'. An alliance between the Order of Headless Monks, the cult of the Silence, and what is later identified as the 'Kovarian Chapter' are identified as working against the Doctor.

In Moffat's episodes two different political visions of the Church emerge. The first sees the Church as a force for maintaining the public good through actively protecting it from forces which might otherwise undermine or damage it. This is very clearly the position adopted in the 'Time of the Doctor'. The overarching aim of the Church is to prevent fighting that will break out should the Doctor reveal his long-hidden name on the planet Trenzalore. This announcement would lead to the Time Lords returning to the Universe, reigniting the catastrophic Time War. As Tasha Lem, the 'Mother Superious' of the Church declares in the episode: 'I dedicate this church to one cause. Silence. The Doctor will not speak his name, and war will not begin.' For Lem, the Church is willing to work with the Doctor to achieve their aims. As she notes in her narration: 'the Papal Mainframe strove to maintain the peace between the Doctor and his enemies'. The Church, in other words, has a role somewhat analogous to the United Nations or European Union. In some respects, this is similar to the position of the body known as the Shadow Proclamation in Russell T Davies's time on the show: an intergalactic court and legal assembly, referenced frequently, but appearing most prominently in 'The Stolen Earth' (2008) (and reappearing under Moffat in 2015's 'The Magician's Apprentice'). Yet whereas the Shadow Proclamation appeared as a body that was appealed to and in which debates were contested, the Church is shown to be much more active. It seeks to deliberately involve itself in interplanetary affairs without waiting for potential combatants to appeal to its authority. In other words, the Church has confidence in its own position; whereas the Shadow Proclamation was legitimated by the consent of its members, the Church works on the basis of its own rights. 
Nonetheless, there are also certain limits to the actions taken by the Church. While it acts from its own interests, it does not see itself as a combatant in the battle for Trenzalore. Instead, it sees its role as being to keep the peace: 'We maintain the truce by blocking all of them [the Doctor's enemies].' This commitment to preventing conflict can be contrasted with the actions of the Kovarian Chapter in 'A Good Man Goes to War'. As opposed to the reactive approach of the central body of the Church, the Chapter believed that it had to actively intervene in events in order to prevent catastrophe. The actions carried out in 'A Good Man Goes to War' are therefore revealed to be unsanctioned by the Church in 'Time of the Doctor': 'The Kovarian Chapter broke away. They travelled back along your timeline and tried to prevent you ever reaching Trenzalore'.

There are several important differences between the Church and the Chapter that can be detected here. The role of ecclesiastical authority is obviously one of these (the Chapter being a break away order) but their interpretations of the relationship between the Church and society also sharply diverge. The Church views their role as peace keeping - intervening militarily only in order to maintain the public good, which at Trenzalore, is in keeping with the Doctor's aims. Their position can be contrasted with that of the Kovarian Chapter, who believe that religious organisations should incite military conflict against the 'sinful'. These two pictures of religious politics in Moffat's Doctor Who might therefore be taken as representing the acceptable and unacceptable faces of a religious engagement in the public sphere: the cautious approach of the Papal Mainframe as opposed to the violent fundamentalism of the Kovarian Chapter. In one sense, these two positions can be traced back to the political theology of Augustinian realism. As St. Augustine (350 - 430 C.E.) argued, the Church recognised the imperfection and sinfulness of the present world, but did not try to remould it into paradise (an impossible task, doomed to failure). They accepted, in other words, that the Kingdom of God was not something that could be brought about through political means. Instead, believers had to wait patiently for the full manifestation of Christ's kingdom (Landes 2010).

A powerful counter-narrative to this Augustinian view has been a millenarian impulse to try and carve the Kingdom out of existing political reality. The Kovarian Chapter embody this kind of reading of history, holding to an apocalyptic-dualistic view of the world in which the Doctor has taken on the Satanic role. The world is conceived in Manichean terms, what Dick Anthony and Thomas Robbins describe as the 'exemplary dualism' (Anthony and Robbins, 
1996; 1997). From their perspective, the Chapter are engaged in an 'endless, bitter war... Against you Doctor'. With this in mind, it is interesting to note that the Chapter are more explicitly theological than the Church. As mentioned above, while the Church make references to faith and the afterlife, and Father Octavian talks about prayer, it is difficult to get any firm idea of their theology. In other words, their service to the public good does not need to be justified - to the Doctor at least - as a mission from God. At one point, when their attempt to defend Trenzalore appears to be failing, Tasha Lem is willing to go so far as talk about an 'unscheduled faith change. From this moment on, I dedicate this church to one cause. Silence.' This implies that the Church's concern for the public good outweighs its theological considerations. This is not the case with the Chapter. In trying to encourage his troops in 'A Good Man Goes to War', military leader Colonel Manton reminds the Chapter that 'We are soldiers of God. We are not fools'. But as soldiers of God, the Chapter feel it is their duty not merely to react to events, as is the case with the Church, but rather to directly agitate; to head off what they view as an apocalyptic confrontation that will take place at Trenzalore by ensuring that the Doctor never reaches the planet. Ironically, as the Doctor notes, it was their attempt to do this (through the destruction of his TARDIS and attempts to develop an assassin to use against him) that finally brought him to the planet.

The Kovarian Chapter might therefore be seen to embody a religious engagement with the political that mirrors that of a number of apocalyptic terror groups. The Doctor's attempt to use 'reason' to outwit the group falls flat, because he is unable to comprehend their apocalyptic mindset. To borrow the concept Michael Barkun has applied to the 1993 Branch Davidian siege at Waco, the apocalyptic script of all-out war leads to a tragic circuit of understanding in which the radically dualistic beliefs of the religious group are often unintentionally supported by their antagonist. The Davidians, an offshoot of the Seventh Day Adventists led by the charismatic David Koresh, believed from their interpretation of scripture that they would face an imminent apocalyptic battle against a Babylonian world system. This system was represented by the UN and US government, and would seek to attack and persecute them. When, in February 1993, they were raided by the Bureau of Alcohol, Tobacco and Firearms, leading to a prolonged siege under FBI jurisdiction, these prophecies appeared to have been fulfilled. FBI actions during the 1993 siege played into their prophetic preconceptions: mocking and refusing to continence their belief in prophecy, while at the same time inadvertently confirming the prophecies through their actions, playing 
out the 'apocalyptic script' held by the religious movement. Conversely, the government's own dualistic script - which viewed the Davidians as brainwashed cultists and failed to consider or engage with their theological interpretation of the situation - was itself reenforced by the believers' actions. With neither side able to comprehend the other's worldview, the violent culmination of the siege in April 1993 became tragically inevitable (Barkun 1996). The same thing occurs in the Doctor's engagement with the Kovarian Chapter. $\mathrm{He}$ is unable to comprehend that they see him as an almost Satanic force in his discussions with their leader, Madam Kovarian, or that his actions have supported this interpretation. Yet we learn that for some of those opposing him, his actions have led to the word 'Doctor' being translated not as 'Healer' but as 'Warrior'. He becomes, in reality, the image that the Kovarian Chapter holds. River Song reminds him: 'This was exactly you. All this. All of it. You make them so afraid... did you ever think you'd become this? The man who can turn an army around at the mention of his name. Doctor.'

This brings us back to the Church itself. Marcus Harmes has argued persuasively that the Church we find in the fifty-first century is radically de-theologised; a secular institution for a secular time (Harmes 2013b). While this is correct up to a point, ironically the sort of role Moffat imagines for the Church in 'The Time of the Doctor' chimes with the positions of one of the most controversial movements in contemporary theology - Radical Orthodoxy.

Radical Orthodoxy is a highly complex and diverse theological movement, whose proponents hold to a range of different positions. Pioneered by theologians such as John Milbank, Catherine Pickstock and Graham Ward, Radical Orthodoxy attempts to reassert the primacy of theology in public and academic debate. Making (an often highly critical) use of postmodern philosophy and continental theology, its proponents have tended to assert a particularly important role for the Church. John Milbank's Theology and Social Theory, one of the key texts in the development of Radical Orthodoxy, therefore argued strongly that there was no such thing as the secular realm. The idea of the 'secular' as an area outside of God's purview and the Church's influence was one of the corrupt developments to spring from medieval philosophy. Driven forward in the Enlightenment, this has led to a situation in which the Church is viewed as irrelevant; not only as lacking in actual political influence, but being actively discouraged from meddling in the secular realm. Discourses of 'tolerance' and 
'equal rights' are used as a justification to keep the Church out of the public sphere, while disguising the fact that the supposedly neutral secular realm is in fact marked by hegemonic capitalism and violence. Opposed to this, the Church is seen as representing true politics: 'All "political" theory, in the antique sense, is relocated by Christianity as thought about the Church.' (Milbank 2006, 410). The very concept of a secular political realm is therefore an illusion, in that it wrongly posits the idea that certain areas are off-limits for Church comment and guidance. Indeed, for Milbank, this represents the state trespassing on the Church's territory - in that the state views itself as managing secular goods without reference to the ultimate good (God, who can be experienced only through the Church) (Milbank 2006).

Other writers working under the umbrella of Radical Orthodoxy develop this further. William T. Cavanaugh, for example, argues that the rise of the State occurred earlier than many historians claim - and that by the fifteenth century the Church was being seen as subservient to the needs of statecraft. The Church's role became limited to privatised conceptions of 'religion', with the state emphasising the danger of the religious wars of the early modern period as a method of keeping the Church in check. The irony, according to Cavanaugh, is that the so-called religious wars themselves were fuelled by politiques and state considerations rather than by religion. From his perspective, any calls for Christians to 'get involved' in politics are little more than asking that individuals play by the state's rules. Such individual participation is useless unless it takes place within a 'disciplined church body'. The Church's role is thus to resist the 'myth of the state as peacemaker as that which takes up and reconciles the contradictions of civil society.' (Cavanaugh 2009, 331). The Church thus acts as a multinational 'community of peace' actively engaging and critiquing the state.

Milbank is even more forceful. Criticising the liberal state, which he sees as replacing ecclesiastical authority, he argues that contemporary Europe is returning to a situation which is akin to Christendom of the middle ages - a collection of nominal states which looked to an extra-national body (in this case the EU) which has an unclear role in overseeing national laws. Such a situation, Milbank claims, calls for a return to the Church as an external authority from the state as a way of preventing what he sees as a slide towards global violence: 'Only a global liturgical polity', he writes, 'can save us now from literal violence.' (Milbank 2009, 358). 
On a critical level, it could be asserted that this appears to be a return to worst excesses of medieval Christendom, such as the 'two swords' model of the church articulated by Pope Boniface VIII in his 1302 Bull Unam Sanctam. The Church controls two swords - the spiritual being superior and wielded by the priest; the temporal being inferior and wielded by rulers and soldiers by the permission of the Church. Should the temporal ruler or power be guilty of sin, 'it is to be judged by the spiritual authority' (Boniface VIII 1302). Yet Radical Orthodoxy's view of the Church is more complex than this. Milbank acknowledges that Church structures (whether Catholic or Protestant) have been overly hierarchal at times. The Church is not, for Milbank, a mirror-image of the state (which would simply replicate the structures of sin he critiques), but a community in which a new social consciousness can emerge (along Christian Socialist lines): 'Better, then, the bounds of Church and State [should] be extremely hazy, so that a "social" existence of many complex and interlocking powers may emerge, and forestall either a sovereign state, or a statically hierarchical Church.' (Milbank 2006, 413). Yet a recurrent criticism of Radical Orthodoxy has been that for all the subtlety of its proponents' positions, the idea of a dominant, yet curiously unspecific Church structure emerges as a utopian and potentially imperialistic vision of a new political order (Shakespeare 2007, 93-94). It is quite difficult to imagine what Milbank's 'global liturgical polity' would look like in practice.

Ironically, this image of the Church is what 'The Time of the Doctor' reveals - a galactic liturgical polity, one in which liturgy (in terms of prayers, ecclesiological language and confession) is the everyday language of a body which ensures that the public good is maintained. While we might be presented with a Church which appears to eschew theology, it is a model which initially fits with the propositions of Radical Orthodoxy - that the state requires some form of ecclesiastical internationalism to contain it. Of course, there is one area in which Radical Orthodoxy would have a major dispute with the Church of the fifty-first century: its obvious willingness to use violence as deterrent. Radical Orthodoxy emerged as a pacifist theology, seeing itself as opposed to the violence that was implicit in contemporary secular political discourse. Broadly speaking, God's rejection of violence was shown through Christ's submission to it in his crucifixion, and his overcoming of it in his resurrection (Shakespeare 2007, 1-40). This has led many theologians working within Radical Orthodoxy to suggest that the Church should radically reject violence at all times (see, for example, 
Daniel Bell's work). But even here there are theological principles which could be used to justify support for involvement in violence. A recent debate between Catholic neoconservative George Weigel and Rowan Williams on Just War Theory, for example, while disagreeing on some fundamental elements of the theory, nonetheless reached agreement that any recourse to war should be understood against an Augustinian background of the necessity of force in protecting the tranquillitas ordinis (Williams and Weigel 2004), or what Weigel describes as 'the dynamic and rightly ordered political community' (Weigel 2003). Neither Williams nor Weigel suggests that the Church should be the one doing the fighting, but the idea of the use of force to protect the tranquillitas ordinis is exactly how we see the Church behave in 'The Time of the Doctor'. As Tasha Lem tells the Doctor: 'None of this was for you, you fatuous egotist. It was for the peace'. In this way, perhaps Moffat's vision of the Church can act as a critique of the ecclesiology envisaged by Radical Orthodoxy. Where Milbank may see the Church as a peaceful force, Moffat implies that maintaining the peace, and the power to do so, will always require, or at least present the temptation to resort to force. Milbank and other theologians within Radical Orthodoxy are alive to the dangers of the Church mirroring the violent structures of the world, but the struggle to articulate a workable vision of the Church that would avoid these pitfalls opens their practicality of their position to criticism. In daring to imagine what such a structure would look like in practice, Doctor Who can work as an point of contact with (and implicit critique of) Radical Orthodoxy.

The aim of this article has not been to suggest that Moffat or his fellow producers are seriously suggesting ways in which the Church of England's ecclesiology should develop their vision is satirical and incongruous. Yet the fact that a major British television programme chose to give the Church such prominence within its diegesis is suggestive of the public interest and continued awareness of its importance to British culture and history. It suggests that writers such as Moffat are more willing to engage with presentations of the Church and religious themes in mainstream television than might initially be thought. Through doing so, the programme engages in a form of theological reflection whether it aims to or not - whether imagining the role faith plays in creating the Doctor as an evil 'other' for the Kovarian Order, or in exploring the way in which the fifty-first century Church intervenes in politics. As such, it helps to comment upon the continuing messy reality of church-state relations in the twenty-first century. 


\section{References}

Anthony, D. and Robbins, T. (1996), 'Religious Totalism, Violence and Exemplary Dualism' in M. Barkun (ed.), Millennialism and Violence, London: Frank Cass, pp. 10-50.

Anthony, D. and Robbins, T. (1997), 'Religious Totalism, Exemplary Dualism, and the Waco Tragedy' in T. Robbins and S. J. Palmer (eds), Millennium, Messiahs and Mayhem, New York and London: Routledge, pp. 261-284.

Balstrup, Sarah, (2014), 'Doctor Who: Christianity, Atheism, and the Source of Sacredness in the Davies Years', Journal of Religion and Popular Culture 26:2, pp. 145-156.

Barkun, M. (1996), 'Introduction' in M. Barkun (ed.) Millennialism and Violence, London: Frank Cass, pp. 1-9.

Boniface III (1302), ‘Unam Sanctam', http://www.papalencyclicals.net/Bon08/B8unam.htm. Accessed $26^{\text {th }}$ May 2016.

Brown, C. G. (2009), The Death of Christian Britain: Understanding Secularisation 18002000 Second Edition, London: Routledge.

Brown, C. and Lynch, G. (2012), 'Cultural Perspectives' in L. Woodhead and R. Catto (eds), Religion and Change in Modern Britain. London: Routledge, pp. 329-351. 
Bruce, S. (2011), Secularization: In Defence of an Unfashionable Theory, Oxford: Oxford University Press.

Cavanaugh, W.T. (2009), “"A Fire Strong Enough to Consume the House”: The Wars of Religion and the Rise of the Nation State' in J. Milbank and S. Oliver (eds), The Radical Orthodoxy Reader, London: Routledge, pp. 314-337.

Crome, A. (2013), 'Introduction', in A. Crome and J. McGrath (eds) Time and Relative Dimensions in Faith: Religion and Doctor Who, London: Darton, Longman and Todd, pp. xi-xxiv.

Crome, A. (2015), 'Implicit Religion in Popular Culture: The Case of Doctor Who', Implicit Religion 18:4, pp. 439-455.

Glover, D. (2011), Turbulent Priests? The Archbishop of Canterbury in Contemporary English Politics, London: Theos.

Gregory, B. S. (2012) Unintended Reformation: How a Religious Revolution Secularized Society, Cambridge, MA.: Harvard University Press. 
Guest, M., Olson E. and Wolffe J. (2012), 'Christianity: Loss of Monopoly' in L. Woodhead and R. Catto (eds), Religion and Change in Modern Britain, London: Routledge. pp. 57-78.

Harmes, M. (2013a), 'Martians, Demons, Vampires, and Vicars: The Church of England in Post-War Science Fiction', Journal of Religion and Popular Culture 25:2, pp. 217-229.

Harmes, M. (2013b), 'The Church Militant? The Church of England, Humanity and the Future in Doctor Who' in A. Crome and J. McGrath (eds) Time and Relative Dimensions in Faith: Religion and Doctor Who, London: Darton, Longman and Todd. pp. 221-234.

Hill, J. (2016), 'Subverting the Sitcom from Within: Form, Ideology and Father Ted' in J. Kamm and B. Neumann (eds), British TV Comedies: Cultural Concepts, Contexts and Controversies. Basingstoke: Palgrave MacMillan. pp. 225-239.

Hjarvard, S. (2011), 'The Mediatisation of Religion: Theorising Religion, Media and Social Change', Culture and Religion 12:2, pp. 119-135.

Holmhead, L. (2007), 'Dibley Criticised for Campaign Plug', The Guardian 18 June. http://www.theguardian.com/media/2007/jun/18/bbc.broadcasting1. Accessed $19^{\text {th }}$ Feb 2016.

Hrotic, S. (2014), Religion in Science Fiction: The Evolution of an Idea and the Extinction of a Genre, London: Bloomsbury. 
Knox, S. (2014), 'The Transatlantic Dimensions of the Time Lord: Doctor Who and the Relationships between British and North American Television' in A. O'Day (ed.), Doctor Who: The Eleventh Hour. London: I.B. Tauris. pp. 106-120.

Krämer, L. (2016), 'Comic Strategies of Inclusion and "Normalisation” in The Vicar of Dibley' in in J. Kamm and B. Neumann (eds), British TV Comedies: Cultural Concepts, Contexts and Controversies. Basingstoke: Palgrave MacMillan, pp. 212-224.

Landes, R. (2011), Heaven on Earth: The Varieties of the Millennial Experience, New York and Oxford: Oxford University Press.

McLeod, H. (2007), The Religious Crisis of the 1960s. Oxford: Oxford University Press.

Milbank, J. (2006), Theology and Social Theory: Beyond Secular Reason, Second Edition, Oxford: Blackwell.

Milbank, J. (2009), 'The Gift of Ruling' in J. Milbank and S. Oliver (eds), The Radical Orthodoxy Reader, London: Routledge, pp. 338-362. 
Office for National Statistics (2012), 'Religion in England and Wales 2011'. http://www.ons.gov.uk/ons/dcp171776_290510.pdf. Accessed 26 $6^{\text {th }}$ May 2016.

Shakespeare, S. (2007). Radical Orthodoxy: A Critical Introduction, London: SPCK.

Ward, G. and Hoelzl, M. (2008), 'Introduction' in G. Ward and M. Hoelzl (eds), The New Visibility of Religion: Studies in Religion and Cultural Hermeneutics, London: Continuum.

Weigel, G. (2003), 'Moral Clarity in a Time of War', First Things 129, pp. 20-27.

Williams, R. and Weigel, G. (2004), 'War and Statecraft: An Exchange', First Things 141, pp. $14-21$.

\section{Television Programmes}

Doctor Who (1963-1989, 1996, 2005-, UK: BBC)

Father Ted (1994-1997, UK: Channel 4)

Rev. (2010-2014, UK: BBC)

The Vicar of Dibley (1994-2007, UK: BBC) 